\title{
The Effect of Health Education on Control Glycemic at Type 2 Diabetes Mellitus Patients
}

\author{
Rusdiana Rusdiana $^{1 *}$, Maya Savira ${ }^{2}$, Sry Suryani Widjaja ${ }^{1}$, Dedi Ardinata $^{2}$ \\ ${ }^{1}$ Department of Biochemistry, Faculty of Medical, University of Sumatera Utara, Jl. Dr. Mansur Kampus USU Medan, 20155, \\ Indonesia; ' Department of Physiology, Faculty of Medical University of Sumatera Utara, Jl. Dr. Mansur Kampus USU Medan, \\ 20155, Indonesia
}

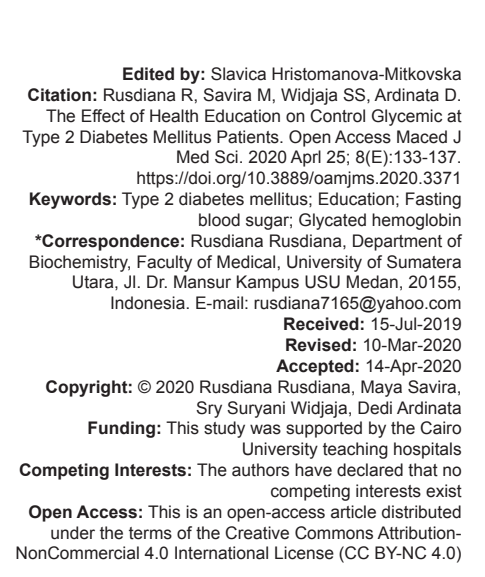

Introduction

Diabetes mellitus is a metabolism disorder, a major clinical, and public health problem. In 2011, the global prevalence of diabetes was 366 million and caused 4.6 million deaths [1]. This figure is expected to rise to 552 million by 2030 and will be the $7^{\text {th }}$ leading cause of death [1], [2]. Indonesia is the world's fourth most populated country, has the seventh-largest number of diabetic patients (7.6 million), and despite relatively low prevalence $(4.8 \%$, including both diabetes type 1 and 2 in individuals aged 20-79 years) in 2012 [3]. The prevalence of diabetics in North Sumatra in 2013 was $1.8 \%$ higher than the national rate, and the results of the previous Indonesian Basic Health Research were 0.8\% and $2.3 \%$, the prevalence of diabetes diagnosed by doctors based on symptom interviews was also higher than the national figure $(2.1 \%)$ [4]. Diabetes mellitus is an important health problem due to its high morbidity and mortality [5]. The prevalence of diabetes mellitus in urban Indonesia is $5.7 \%$ [6], and the incidence of diabetes mellitus is starting to rise at a younger age [7].
American Diabetes Association (ADA) suggested glycemic control as one of the important strategies for the management of type 2 diabetes mellitus and glycosylated hemoglobin which is the best measure of glycemic level over the previous 3 months [8]. The management of diabetes is dependent to a great extent on the affected person's own abilities to carry out self-care in his daily lives and patients' educations are considered an essential component of achieving this objective [9]. There is evidence that people affected with the disease often have inadequate knowledge about the nature of diabetes, its risk factors and associated complications, and that this lack of awareness may be the underlying factor affecting attitudes and practices toward its care [10]. Stabilization of blood glucose is the primary goal of diabetes management [11]. This depends on carrying out a number of different self-care behaviors and complex management regimens involving exercise, dietary modification, foot care, self-monitoring glycemic control, and administration of medications [12]. Giving education for diabetes mellitus patients, consequent improvement in knowledge, attitudes, and skills, leads to better control of the disease and is widely accepted 
to be an integral part of comprehensive diabetes care [13]. Many factors are shown to affect the health of individuals and communities. One of these factors is the low education level, which is linked with poor health, more stress, and lower self-confidence [14]. It was documented in some studies that low educational status had been associated with a negative effect on glycemic control [15], while others have shown that educational status had no effect on glycemic control [16]. Diabetes education is considered to be essential in reaching good glycemic control [17].

The aim of this research was to provide health education for type 2 diabetes mellitus education to increase the knowledge of self-management principles and skills to achieve sufficient glycemic control.

\section{Methods}

Patients were recruited from Medan Johor Primary Health Care (PHC), North Sumatera, Indonesia. This was conducted from April to September 2018, we took 40 samples of type 2 diabetes mellitus who attend for controlled from this $\mathrm{PHC}$. This is a quasi-experimental research with one group pretest-posttest design. In accordance with the inclusion criteria which are: age $>40$ years old and cooperative and have a will to join this research, and exclusion criteria which are: letter less, seriously ill such as cardiovascular disease, and the middle of cancer therapy. All participants gave written, informed consent to participate in the study. This research was approved by Health Research Ethical Committee, Medical Faculty of University of Sumatera Utara/H. Adam Malik General Hospital by number 591/TGL/ KEPK FK USU-RSUP HAM/2017.

Before starting education activities, each sample we examine weight, height, waist size, blood pressure, and laboratory tests such as fasting blood sugar (FBS) levels and glycated hemoglobin (HbA1c). FBS of samples were measured using a portable measuring instrument (Gluco DR). Blood samples were collected (using syringe) twice before and after intervention by education and transferred to Pramita Clinic Laboratory immediately to be conducted glycosylated hemoglobin test by HPLC method.

The participants completed a general information form included question on age, marital status, family history of the disease, duration of the disease, clinical characteristics, awareness of diabetic complications, taking oral diabetic or insulin injection, smoking, following any diet, daily activity, education level, and job. We recorded the last reading for $\mathrm{HbA1c}$ for each patient. Education intervention was conducted in type 2 diabetes mellitus samples for 3 months containing lectures and discussion.
At the meetings, they were recommended and gave the information about diabetes and its complications, proper diet, exercise every day at least 30 min such as bike, walking, and aerobic, taking education regularly as directed by the physician, self-monitoring patient's blood sugar, diabetic foot care, and not smoking. Each giving education, we always examine weight, waist size, blood pressure, and FBS.

The education services included, about selfmanagement plan like examined FBS by self with the portable measuring instrument, and injected insulin by self, knowledge about glycemic control by $\mathrm{HbA} 1 \mathrm{C}$ every 3 months. Since almost all patients did not know about $\mathrm{HbA} 1 \mathrm{c}$, they just know that FBS examination was enough for glycemic control. We explain about using our country's health insurance for every control in the PHC. Furthermore, we gave the patient diet and exercise management. Giving the education for diabetes mellitus patients was necessary for increasing of the understanding the patients about the disease because there were still many type 2 diabetes mellitus patients that have a lack of knowledge about the management of the disease both about the diet and the physical exercise. We advised the patients for exercise every day minimal for $30 \mathrm{~min}$. Every month until 3 months, we gave the education and we always examine FBS the patients every month and in the $3^{\text {rd }}$ month, we examined $\mathrm{HbA} 1 \mathrm{c}$ for the patients. In this study, we determined $\mathrm{HbA} 1 \mathrm{c}<6.5 \%$ as an indicator for the control of type 2 diabetes mellitus. The continuous data were expressed as the mean \pm standard deviation (SD). Shapiro-Wilk test was used for checking the normality of distribution. If the data were normally distributed, a t-test was used. Otherwise, a nonparametric test was applied.

\section{Results}

The samples of the study in Johor of Public Health Care were 40 subjects. The number of female subjects was $30(75 \%)$ and male was $10(25 \%)$, achieved the assigned target of interviews before and after intervention. The demographic data were gender, age-group, education level, family history, and type of treatment Table 1. We gave the leaflet for the samples which the content about the management diet and physical exercise. The education for 3 months was only about the management diet, physical exercise for the samples, and complication the illness. We recommended blood sugar level examination of the samples once a month and Hba1c value examination every 3 months. The samples who received health education were the same with pre-education. We tried to encourage the sample to follow the diet and exercise arrangements as contained in the leaflet that we provide. 
Table 1: The content of the education program for the patients

\begin{tabular}{|c|c|c|}
\hline \multicolumn{3}{|l|}{ Management diet } \\
\hline Menu for breakfast & Menu for lunch & Menu for dinner \\
\hline $100 \mathrm{gr}$ red rice bread & $150 \mathrm{~g}$ red rice & $100 \mathrm{gr}$ red rice or $1-4$ sheet of \\
\hline $100 \mathrm{gr}$ boiled vegetables & 1 bowl of vegetables & $1-2$ grilled eggplant \\
\hline One egg & $50 \mathrm{~g}$ sweet and sour fish & $500 \mathrm{~g}$ grilled chicken 1 pear \\
\hline $1 / 2$ avocado & $\begin{array}{l}1 \text { piece of tofu meatballs } \\
1 \text { orange }\end{array}$ & \\
\hline \multicolumn{3}{|c|}{ Management physical exercise } \\
\hline Kind of physical exercise & \multirow{3}{*}{\multicolumn{2}{|c|}{$\begin{array}{l}\text { Duration of sports } \\
\text { Ideal time about } 20-60 \text { min } 3-5 \text { times in a week, } \\
\text { Duration for DM with obesity must reach } 60 \text { min }\end{array}$}} \\
\hline Jogging & & \\
\hline Cycling & & \\
\hline \multicolumn{3}{|l|}{ Brisk walking } \\
\hline \multicolumn{3}{|l|}{ Swimming } \\
\hline \multicolumn{3}{|l|}{ Gymnastics } \\
\hline Aerobic & & \\
\hline
\end{tabular}

The baseline of the characteristic of the samples, the mean of age was $62.53 \pm 7.81$ years old, the mean of body mass index of the samples was 24.81 $\pm 3.18 \mathrm{~kg} / \mathrm{m}$, the mean of the waist size of the samples was $92.15 \pm 8.62 \mathrm{~cm}$, the mean of FBS of the samples was $238.83 \pm 88.75 \mathrm{mg} / \mathrm{dl}$, and the mean of HBA1c of the samples was $8.90 \pm 1.81 \%$ [Table 2].

Table 2: Respondent characteristic

\begin{tabular}{|c|c|c|}
\hline Parameter & $\mathrm{n}$ & $\%$ \\
\hline \multicolumn{3}{|l|}{ Gender } \\
\hline Male & 10 & 25 \\
\hline Female & 30 & 75 \\
\hline \multicolumn{3}{|l|}{ Age group } \\
\hline Early elderly $(40-55$ y) & 11 & 27.5 \\
\hline Further elderly (55-65 y) & 15 & 37.5 \\
\hline Seniors $(>65 \mathrm{y}$ ) & 14 & 35 \\
\hline \multicolumn{3}{|l|}{ Education levels } \\
\hline Primary high school & 2 & 5 \\
\hline Junior high school & 12 & 30 \\
\hline Senior high school & 14 & 60 \\
\hline Academy university & 2 & 5 \\
\hline \multicolumn{3}{|l|}{ Familial history } \\
\hline Maternal history & 4 & 10 \\
\hline Paternal history & 6 & 15 \\
\hline Not knowing & 30 & 75 \\
\hline \multicolumn{3}{|l|}{ Management of diet } \\
\hline Regular & 12 & 30 \\
\hline Irregular & 28 & 70 \\
\hline \multicolumn{3}{|l|}{ Type of physical activity } \\
\hline Jogging & 15 & 37.5 \\
\hline Aerobic & 3 & 7.5 \\
\hline Cycling & - & - \\
\hline No activity & 22 & 55 \\
\hline \multicolumn{3}{|l|}{ Type of treatment } \\
\hline Oral diabetic & 38 & 95 \\
\hline Insulin injection & 2 & 5 \\
\hline
\end{tabular}

This study aimed to analyze the comparison of $\mathrm{HbA} 1 \mathrm{c}$ and FBS levels in type 2 diabetes mellitus pre-intervention (pre-test) and post-intervention (post-test) with education, so we used the statistical analysis with the continuous data were expressed as the mean \pm SD. Shapiro-Wilk test was used for checking the normality of distribution [Table 3].

Table 3: Baseline characteristic of the participants

\begin{tabular}{llllll}
\hline Parameter & $\mathrm{n}$ & \multicolumn{3}{l}{ Descriptive statistics } \\
\cline { 3 - 4 } & & Minimum & Maximum & Mean & Std. deviation \\
\hline Age $(\mathrm{years}$ old $)$ & 40 & 48 & 77 & 62.53 & 7.81 \\
BMl $\left(\mathrm{kg} / \mathrm{m}^{2}\right)$ & 40 & 18.55 & 31.16 & 24.81 & 3.18 \\
Waist size $(\mathrm{cm})$ & 40 & 73 & 106 & 92.15 & 8.62 \\
$\mathrm{FBS}(\mathrm{mg} / \mathrm{dl})$ & 40 & 110 & 500 & 238.83 & 88.75 \\
HbA1c $(\%)$ & 40 & 6.00 & 14.00 & 8.90 & 1.81 \\
Systole & 40 & 90 & 160 & 127.60 & 13.23 \\
Diastole & 40 & 60 & 100 & 81.63 & 8.35 \\
Valid $\mathrm{n}$ (listwise) & 40 & & & & \\
\hline HbA1c: Glycated hemoglobin, BMl: Body mass index.
\end{tabular}

If the data were normally distributed, a paired $t$ test was used. The data of FBS before and after education used paired $t$ test and the data of $\mathrm{HbA1c}$ were analyzed using the Wilcoxon test. There was significantly FBS before and after education $(p<0.005)$, but there was no significantly $\mathrm{HbA} 1 \mathrm{c}$ value of the samples before and after education $(p>0.005)$ [Table 4].

Table 4: Percentage of respondents, controlled diabetes mellitus before and after the health education intervention

\begin{tabular}{llll}
\hline Parameter & \multicolumn{2}{l}{ Mean $( \pm$ SD) } & $\mathrm{p}$ \\
\cline { 2 - 3 } & Before education & After education & \\
\hline FBS $(\mathrm{mg} / \mathrm{dl})$ & $238.83 \pm 88.75$ & $216.88 \pm 66.42$ & $0.001^{* *}$ \\
HbA1c $(\%)$ & $8.90 \pm 1.8$ & $8.74 \pm 1.73$ & $0.020^{*}$ \\
Waist size $(\mathrm{cm})$ & $92.15 \pm 8.62$ & $91.6 \pm 8.09$ & 000 \\
BMI $(\mathrm{kg} / \mathrm{m})$ & $24.81 \pm 3.18$ & $24.56 \pm 3.18$ & 0000 \\
\hline "**Wilcoxon signed ranks test, ${ }^{*}$ Paired t-test, HbA1c: Glycated hemoglobin, BMl: Body mass index,
\end{tabular}

SD: Standard deviation.

\section{Discussion}

This study was a randomized and controlled clinical study and evaluated the effect of health education on glycemic control ( $\mathrm{HbA} 1 \mathrm{c}$ and FBS) among adults with type 2 diabetes mellitus patients. The study results indicated a significant decrease on glycemic control on FBS for the type 2 diabetes mellitus participants, but there was no significant $\mathrm{HbA} 1 \mathrm{c}$ value by the end of the health education for 3 months. HbA1c value examination showed that the average level of blood sugar over the past 2-3 months, although we can see on the table the mean of $\mathrm{HbA} 1 \mathrm{c}$ value decreased after education by statistical, it did not show to be significant [18], [19]. Rusdiana et al. assessed the effect of diabetes self-management education on HBA1c level and FBS at type 2 diabetes mellitus patients in $\mathrm{PHC}$ in Binjai city showed that a decrease in $\mathrm{HbA} 1 \mathrm{c}$ and FBS after giving education for 3 months [20], other research showed that educational interventions effectively improved glycemic control and are, thus highly recommended for diabetic patients [21]. Furthermore, the other research about analysis of factors affecting the selfcare behaviors of diabetes mellitus type 2 patients in Binjai, North Sumatera - Indonesia showed that selfcare behaviors of type 2 diabetes mellitus in Binjai are significantly influenced by motivation, self - efficacy, communication, knowledge, and attitude [22], [23]. The other research about the effect of education at type 2 diabetes mellitus from a local Chinese nonprofit-making organization for diabetic showed that the education effect, even though in low intensity, significantly improved glycemic and body weight control in patients with type 2 diabetes [24]. Many researches have done about giving the education for type 2 diabetes mellitus and always finding the significantly results at control glycemic, Hba1c, or FBS [25].

Our study was a short time, giving the health education, before that we examined the glycemic control $\mathrm{Hba} 1 \mathrm{c}$ and FBS, and our findings suggest that the educational intervention was successful in achieving some significant changes in the lifestyles among our target population; there was a decrease in the number 
of smokers, increase in the intake of a healthy diet concerning eating dates, fat intake, increase vegetable intake, diet soft drinks, and the reason for that change is the doctor's advice and more concern about their health care. Still, many people have not known yet about the control glycemic of HbA1c value; they knew just FBS as a control glycemic for diabetes mellitus, so by this education resulted in achieving a good change in the control of diabetes mellitus (mean $\mathrm{HbA} 1 \mathrm{c}$ ) in the post-educated than the pre-educated groups.

\section{Conclusion}

The conclusion of this study is that improving that the health education in Medan Johor PHC, North Sumatera, increasing awareness for diabetes mellitus patients about exercise such as jogging or aerobic for 30 min every day or awareness of activity daily does not consider exercise. This study has several limitations: A short period of health education and the subjects in the study were also more elder, so our education was less valuable if the subjects more younger than our subjects maybe the results more valuable. In the PHC, we left the leaflet in PHC which content the management of menu and physical exercise by hoping the staff in Public Health Care Clinic can give it for the type 2 diabetes mellitus patients who attend to the $\mathrm{PHC}$, so each the patient type 2 diabetes mellitus except in our research can receive this education, so the aim of the study can be reached for reducing the glycemic control, especially the $\mathrm{HbA1c}$ value. Finally, it is expected that the impact of health education intervention may have been shortlived, as observed in several other studies.

\section{Acknowledgments}

The authors gratefully acknowledge that the present research is supported by Ministry of Research and Technology and Higher Education Republic of Indonesia. The support is under the research grant BP-PTN USU of the Year 2018 Contract Number: 176/ UN5.2.3.2.1/PPM 2018

\section{References}

1. World Health Organization. Global Status Report on Noncommunicable Diseases 2010. Geneva: World Health organization; 2011

2. King H, Aubert RE, Herman WH. Global burden of diabetes,
1995-2025: Prevalence, numerical estimates, and projections. Diabetes Care. 1998;21(9):1414-31. https://doi.org/10.2337/ diacare.21.9.1414

PMid:9727886

3. Shaw JE, Sicree RA, Zimmet PZ. Global estimates of the prevalence of diabetes for 2010 and 2030. Diabetes Res Clin Pract. 2010;87(1):4-14. https://doi.org/10.1016/j.diabres.2009.10.007 PMid:19896746

4. Kesehatan RI. Tahun 2030 Prevalensi Diabetes Mellitus di Indonesia Mencapai 21, 3 Juta Orang. Indonesia: Sekretariat Jenderal Departemen Kesehatan; 2009. p. 17.

5. Wild S, Roglic G, Green A, Sicree R, King H. Global prevalence of diabetes: Estimates for the year 2000 and projections for 2030. Diabetes Care. 2004;27(5):1047-53. https://doi. org/10.2337/diacare.27.5.1047

PMid:15111519

6. Mihardja L, Delima T, Siswoyo H, Ghani L, Soegondo S Prevalence and determinants of diabetes mellitus and impaired glucose tolerance in Indonesia. Acta Med Indones. 2009;41(4):169-74.

PMid:20124611

7. Chan JC, Malik V, Jia W, Kadowaki T, Yajnik CS, Yoon KH, et al. Diabetes in Asia: Epidemiology, risk factor, and pathophysiology. JAMA. 2009;41:169-74.

8. American Diabetes Association. Standards of medical care in diabetes. Diabetes Care. 2013;3 Suppl 1:S11-66.

PMid:23264422

9. Nicolucci A, Ciccarone E, Consoli A, Di Martino G, La Penna G Latorre A, et al. Relationship between patients practice-oriented knowledge and metabolic control in intensively treated Type 1 diabetic patients: Results of the validation of the knowledge and practices diabetes questionnaire. Diabetes Nutr Metab. 2000;13(5):276-83

PMid: 11105970

10. Evert AB, Bocher JL, Cypress M, Dunbar SA, Franz MJ Mayer-Davis EJ, et al. Nutrition therapy recommendations for the management of adults with diabetes. Diabetes Care. 2013;36(11):3821-42. https://doi.org/10.2337/dc13-2901 PMid:24107659

11. Bard E, Clark M, Hurel S, Cooke D. Do people with diabetes understand their clinical marker of long-term glycemic control (HbA1c levels) and does this predict diabetes self-care behaviors and Hba1c? Patient Educ Couns. 2010;80(2):227-32. https://doi.org/10.1016/j.pec.2009.11.008 PMid:20036098

12. Mohan D, Raj D, Shanthiran CS. Awareness and knowledge of diabetes in Chennai-the Chennai urban rural epidemiology study [CURES-9]. J Assoc Physicians India. 2005;53:283-5. PMid:15987011

13. Berger $M$, Muhlhauser I. Diabetes care and patient-oriented outcomes. JAMA. 1999;281(18):1676-8. https://doi.org/10.1001/ jama.281.18.1676 PMid: 10328053

14. Glasgow RE, Osteen VL. Evaluating diabetes education. Are we measuring the most important outcomes? Diabetes Care. 1992;15(10):1423-32 https://doi.org/10.2337/ diacare.15.10.1423

PMid:1425111

15. Coates VE, Boore JR. Knowledge and diabetes selfmanagement. Patient Educ Couns. 1996;29(1):99-108. PMid:9006226

16. Rose M, Fliege H, Hidebrandt M, Schirop T, Klapp BF. The network of psychological variables in patients with diabetes and their importance for quality of life and metabolic control. Diabetes 
Care. 2002;25(1):35-42. https://doi.org/10.2337/diacare.25.1.35 PMid: 11772898

17. Schwartz LS, Coulson LR, Toovy D, Lyons JS, Flaherty JA. A biopsychosocial treatment approach to the management of diabetes mellitus. Gen Hosp Psychiatry. 1991;13(1):19-26. https://doi.org/10.1016/0163-8343(91)90005-h PMid:1993515

18. Tan AS, Yong LS, Wan S, Wong ML. Patient education in the management of diabetes mellitus. Singapore Med J. 1997;38(4):156-60.

PMid:9269394

19. Rubin R. Differential effect of diabetes education on self-regulation and life stage behaviors. Diabetes Care. 1998;14(4):335-8. PMid:2060437

20. Heisler M, Smith DM, Hayward RA, Krein SL, Kerr EA. How well do patients assessments of their diabetes selfmanagement correlate with actual glycemic control and receipt of recommended diabetes services? Diabetes Care. 2003;26(3):738-43. https://doi.org/10.2337/diacare.26.3.738 PMid:12610031

21. Rusdiana R, Savira M, Amelia R. The effect of diabetes selfmanagement education on HbA1c level and fasting blood sugar in Type 2 diabetes mellitus patients in primary health care in Binjai city of North Sumatera, Indonesia. Open Access Maced J Med Sci. 2018;6(4):715-718. https://doi.org/10.3889/ oamjms.2018.169

PMid:29731946

22. Zibaeenzhad MJ, Aghasadeghi K, Baheri FZ, Khalesi E, Zamirian M, Moaref A, et al. The effect of educational intervention on glycemic control in patients with Type 2 diabetes mellitus. Int Cardiovasc Res J. 2015;9(1):17-21

23. Rusdiana R, Savira M, Amelia R. Characteristics of Type 2 diabetes mellitus patients based on blood sugar level and $\mathrm{HbA} 1 \mathrm{c}$ in Binjai public health centres. Adv Sci Lett. 2017;23(4):3599601. https://doi.org/10.1166/asl.2017.9190

24. Amelia R, Lelo A, Lindarto D. Analysis of factors affecting the self-care behaviors of diabetes mellitus Type 2 patients in Binjai, North Sumatera-Indonesia. Asian J Microbiol Biotechnol Environ Sci. 2018;20(2):361-7.

25. Yuan C, Lai CW, Chan LW, Chow M, Law HK, Ying M. The effect of diabetes self-management education on body weight, glycemic control, and other metabolic markers in patients with Type 2 diabetes mellitus. J Diabetes Res. 2014;2014:789761. https://doi.org/10.1155/2014/789761

PMid:25136645 